\title{
Wykorzystanie wywiadów kognitywnych w projektowaniu kwestionariusza wywiadu na przykładzie badania uczenia się osób dorosłych
}

\author{
Paulina Adamczyk \\ Uniwersytet Łódzki \\ Marika Markowska \\ Instytut Badań Edukacyjnych
}

Marta Petelewicz

Uniwersytet Łódzki

Katarzyna Piotrowska

Akademia Leona Koźmińskiego

Joanna Stankowska

Sieć Badawcza Łukasiewicz - Instytut Organizacji i Zarządzania w Przemyśle „Orgmasz"

DOI: http://dx.doi.org/10.18778/1733-8069.17.1.09

Słowa kluczowe: wywiady kognitywne, uczenie się dorosłych, pilotaż pogłębiony

\begin{abstract}
Abstrakt: Artykuł przedstawia analizę wywiadów kognitywnych, które stanowiły pierwszy etap pilotażu kwestionariusza wywiadu w ramach badania „Uczenie się dorosłych Polaków”. Dostępne wyniki badań międzynarodowych wskazują na relatywnie niski poziom uczestnictwa osób dorosłych w edukacji w Polsce, a zarazem różnice w wartości wskaźników w poszczególnych badaniach. Na podstawie przeglądu literatury wnioskować można, że rozbieżności te wynikają z różnic w operacjonalizacji, sposobie agregacji kategorii, jak również innych czynników. Założono, że wykorzystanie wywiadów kognitywnych, w tym technik thinking alo$u d$ i verbal probing, umożliwi dotarcie do sposobów interpretacji pojęć i rozumienia pytań przez respondentów, a także pozwoli badaczom na identyfikację zagadnień o wysokim poziomie drażliwości. Na podstawie wyników obserwacji prowadzonej w trakcie wywiadów oraz analizy zgromadzonego materiału empirycznego omówiono rozbieżne od pierwotnie założonych przez badaczy sposoby konceptualizacji terminów przez badanych, a także kwestie wywołujące dyskomfort respondentów. Zaprezentowano zaproponowane modyfikacje kwestionariusza wywiadu, których celem jest redukcja ryzyka uzyskania wyników nietrafnych, obarczonych wysokim ryzykiem błędu pomiaru oraz troska o dobrostan respondentów związany z sytuacją badania. Przedstawiono również wnioski dotyczące zastosowania techniki wywiadów kognitywnych jako elementu pilotażu badań sondażowych oraz konkluzje o charakterze metodologicznym dotyczące techniki wywiadów kognitywnych.
\end{abstract}


Paulina Adamczyk, doktorantka w Katedrze Socjologii Polityki i Moralności na Wydziale Ekonomiczno-Socjologicznym Uniwersytetu Łódzkiego. Zainteresowana jest problematyką badawczą obejmującą zdrowie psychiczne, ze szczególną koncentracją na dzieciach i młodzieży oraz na tematach związanych z samobójstwem i autodestrukcją.

\section{Adres kontaktowy:}

Katedra Socjologii Polityki i Moralności

Wydział Ekonomiczno-Socjologiczny, Uniwersytet Łódzki

ul. Rewolucji 1905 r. nr 41/43, 90-214 Łódź

e-mail: paulina.maria.adamczyk@wp.pl

Marika Markowska, badacz z wykształcenia, zawodu i zamiłowania. Absolwentka Uniwersytetu Gdańskiego, magister socjologii na specjalności procedury badawcze i analiza danych. Aktualnie pracownik Instytutu Badań Edukacyjnych, badacz społeczny specjalizujący się w metodach jakościowych. Do jej zainteresowań naukowych należą: socjologia kultury, socjologia muzyki, tożsamość jednostki, metodologia badań społecznych.

\section{Adres kontaktowy:}

Instytut Badań Edukacyjnych

ul. Górczewska 8, 01-180 Warszawa

e-mail: m.markowska@ibe.edu.pl

Marta Petelewicz, doktor nauk społecznych, socjolożka, pracowniczka naukowo-dydaktyczna Katedry Socjologii Struktur i Zmian Społecznych Uniwersytetu Łódzkiego. Ekspertka do spraw badań w Instytucie Badań Edukacyjnych. Główne zainteresowania naukowe obejmują metodo- logię badań społecznych, strukturę społeczną, jakość życia oraz uczenie się dorosłych.

\section{Adres kontaktowy:}

Katedra Socjologii Struktur i Zmian Społecznych

Wydział Ekonomiczno-Socjologiczny

Uniwersytet Łódzki

ul. Rewolucji 1905 r. nr 41/43, 90-214 Łódź

e-mail: m.petelewicz@gmail.com

Katarzyna Piotrowska, doktor psychologii, pracownik naukowo-dydaktyczny Katedry Metod Ilościowych i Zastosowań Informatyki Akademii Leona Koźmińskiego. Prowadzi zajęcia ze statystyki oraz metodologii badań społecznych. Specjalista ds. badań i analiz w Instytucie Badań Edukacyjnych.

\section{Adres kontaktowy:}

Akademia Leona Koźmińskiego

ul. Jagiellońska 57/59, 03-301 Warszawa

e-mail: kpiotrowska@kozminski.edu.pl

Joanna Stankowska, absolwentka socjologii i filologii polskiej na Uniwersytecie Mikołaja Kopernika w Toruniu. Badaniami ilościowymi i jakościowymi zajmuje się od prawie 10 lat. Obecnie angażuje się w projekty związane z rynkiem pracy i uczeniem się osób dorosłych.

\section{Adres kontaktowy:}

Sieć Badawcza Łukasiewicz - Instytut Organizacji i Zarządzania w Przemyśle „Orgmasz”

ul. Żelazna 87, 00-879 Warszawa

e-mail: stankowska.joanna@gmail.com
$\mathrm{A}$

rtykuł koncentruje się na analizie wykorzystania wywiadów kognitywnych $\mathrm{w}$ ramach pilotażu kwestionariusza do badania uczenia się osób dorosłych. Przegląd literatury i analiza dostępnych badań ukazały bowiem złożoność zjawiska uczenia się dorosłych, w tym wyraźne rozbieżności w sto- sowanym aparacie pojęciowym (zob. Desjardins 2014; Goglio, Meroni 2014; Worek 2019). Sposób konceptualizacji terminów w środowisku naukowym nie jest $\mathrm{w}$ pełni tożsamy $\mathrm{z}$ ich potocznym rozumieniem, czego przykładami mogą być takie pojęcia, jak warsztaty, kwalifikacje czy samo uczenie się. Pojawiają się zatem problemy z operacjonalizacją ba- 
danych konstruktów w taki sposób, by faktycznie mierzyć to, na pomiarze czego badaczom zależy. Założono, że możliwość poznania nie tylko odpowiedzi respondenta, lecz także procesu dotarcia do niej, którą stwarza wywiad kognitywny (Grzeszkiewicz-Radulska 2012), pozwoli skonfrontować rozumienie przez badanych pojęć i pytań z zamierzeniami badaczy. Problematyka uczenia się w dorosłości stwarza ponadto sytuacje, w których prosi się respondentów o wypowiedzi na tematy będące dla niektórych dalekie od neutralnych ze względu na obowiązujące normy kulturowe i wynikający z nich dyskomfort odpowiadania przecząco na pytania o podejmowanie działań edukacyjnych. Wywiady kognitywne stwarzają możliwość identyfikacji pojęć i pytań najbardziej obciążających dla respondentów. Założono więc, że zastosowane podejście przyczyni się do zminimalizowania ryzyka sformułowania błędnych wniosków, które mogą wynikać ze wspomnianych problemów.

Celem artykułu jest przedstawienie wyników analiz wywiadów kognitywnych w zakresie rozumienia kluczowych pojęć i konstruktów stosowanych w narzędziu badawczym oraz identyfikacji zagadnień obciążających emocjonalnie respondentów. Przedstawiono również przykłady modyfikacji, jakie zostały wprowadzone na podstawie tych analiz do kwestionariusza wywiadu. Zaprezentowane refleksje stanowią próbę odpowiedzi na pytanie dotyczące korzyści płynących z wykorzystania techniki wywiadów kognitywnych w ramach pilotażu tego badania, a także szerzej, badań sondażowych.

Artykuł podzielony jest na pięć części: skrótową charakterystykę badania $\mathrm{w}$ kontekście tematyki uczenia się w dorosłości, prezentację głównych wymiarów jakości pomiarów dokonywanych w tym obszarze, zarys techniki wywiadów kognityw- nych wraz z ich zastosowaniem, analizę wyników z przykładami wykorzystania omówionej metody oraz wnioski z przeprowadzonych badań. Fragment obejmujący analizę materiału badawczego podzielono na dwie części, zgodnie z wyróżnionymi problemami: rozumienie i interpretacja pojęć, w tym sformułowań tworzących pozycje skal, oraz drażliwość pytań.

\section{Badania nad uczeniem się dorosłych jako kontekst realizacji wywiadów}

Celem badania „Uczenie się dorosłych Polaków"1 jest opracowanie pogłębionej i wielowymiarowej charakterystyki zjawiska uczenia się $\mathrm{w}$ dorosłości. Oprócz typowego dla badań z tego obszaru pomiaru poziomu uczestnictwa $\mathrm{w}$ aktywnościach edukacyjnych zaplanowano również stworzenie typologii postaw wobec uczenia się, analizę ich zróżnicowania oraz uwarunkowań. Wywiady kognitywne stanowiły jeden z etapów prac nad kwestionariuszem do badania właściwego, które będzie realizowane techniką CAPI (wywiad kwestionariuszowy wspomagany komputerowo) ${ }^{2}$ na reprezentatywnej próbie dorosłych obywateli Polski w wieku 25-64 lat ( $w$ momencie losowania; $n=7200$ ). Badanie wpisuje się $\mathrm{w}$ nurt analiz kształcenia ustawicznego, czy inaczej uczenia się przez całe życie, obejmującego wszystkie rodzaje uczenia się, podejmowane

\footnotetext{
${ }^{1}$ Badanie realizowane jest przez Instytut Badań Edukacyjnych w Warszawie w ramach projektu: Wspieranie II etapu wdrażania Zintegrowanego Systemu Kwalifikacji na poziomie administracji centralnej oraz instytucji nadajacych kwalifikacje i zapewniajacych jakość nadawanych kwalifikacji POWR.02.13.00-00-0001/18. Uzyskane wyniki posłużą budowaniu polityk publicznych w obszarze edukacji dorosłych w Polsce.

2 Ze względu na pandemię koronawirusa i wprowadzenie $\mathrm{z}$ tego powodu obostrzeń faza terenowa badania głównego „Uczenie się dorosłych Polaków” została przełożona na 8-11.2020; w przypadku respondentów obawiających się o swój stan zdrowia wprowadzono również możliwość realizacji wywiadu przez telefon.
} 
w ciągu całego życia, których celem jest zdobycie i rozwój wiedzy, umiejętności i kompetencji ze sfery życia osobistego, obywatelskiego, społecznego i/ lub zawodowego (Eurostat 2016). Oznacza to, że do poruszanych w badaniu obszarów należy zarówno edukacja formalna, a zatem uczenie się $\mathrm{w}$ ramach systemu oświaty i szkolnictwa wyższego według zatwierdzonych programów, jak i pozostałe formy rozwijania wiedzy i umiejętności, czyli edukacja pozaformalna i nieformalna ${ }^{3}$.

Badania, w których podejmowana jest problematyka uczenia się osób dorosłych, realizowane są przez wiele podmiotów na całym świecie. Wśród najbardziej znanych projektów dostarczających obecnie danych na temat uczestnictwa Polaków w aktywnościach edukacyjnych wymienić należy Badanie Aktywności Ekonomicznej Ludności (BAEL, ang. Labour Force Survey, LFS), badanie Ksztatcenie Dorostych (KD, ang. Adult Education Survey, AES), Bilans Kapitału Ludzkiego (BKL) czy Międzynarodowe Badanie Kompetencji Osób Dorostych (PIAAC, ang. The Programme for the International Assessment of Adult Competencies). Jednym ze wspólnych celów badań ilościowych nad uczeniem się dorosłych jest pomiar poziomu uczestnictwa w aktywnościach edukacyjnych. Porównania wyników uzyskiwanych zarówno w badaniach polskich, jak i międzynarodowych często jednak nie dostarczają spójnych konkluzji w tym zakre-

\footnotetext{
${ }^{3}$ Kształcenie pozaformalne rozumiane jest jako uczestnictwo we wszelkiego rodzaju zorganizowanych kursach, szkoleniach, prywatnych lekcjach, seminariach itd. pozwalających na poszerzanie wiedzy, nabywanie kompetencji, a także zdobywanie nowych kwalifikacji, czasem potwierdzonych certyfikatem, ale nieskutkujące podniesieniem poziomu wykształcenia. Kształcenie nieformalne to zaś samodzielne lub wspólne z innymi osobami, intencjonalne podejmowanie rozmaitych aktywności w celu zdobycia nowej wiedzy lub umiejętności, realizowane w sposób niesformalizowany i często nieustrukturyzowany. Przykładem tego typu działań jest uczenie się nowych rzeczy od członków rodziny, znajomych, przyjaciół, podczas spotkań klubów, kółek zainteresowań, ale także od współpracowników i przełożonych w miejscu pracy.
}

sie. Wyniki badań wskazują na niskie wskaźniki uczenia się osób dorosłych w Polsce w zestawieniu $\mathrm{z}$ innymi krajami, jednakże wnioski dotyczące poziomu uczestnictwa dorosłych w poszczególnych aktywnościach edukacyjnych istotnie się różnią. $\mathrm{Na}$ przykład, według Eurostatu opierającego się na danych z Kształcenia Dorostych, w 2016 roku w Polsce $\mathrm{w}$ różnych formach kształcenia formalnego i pozaformalnego uczestniczyło, jeśli wziąć pod uwage 12 miesięcy poprzedzających badanie, 25,5\% osób w wieku 25-64 lata (w edukacji formalnej 4,4\%, w pozaformalnej 23\%). Natomiast w Bilansie Kapitatu Ludzkiego wskaźnik uczestnictwa dorosłych w edukacji formalnej i pozaformalnej w roku 2017 wyniósł $40 \%$ dla tej samej grupy wiekowej i horyzontu czasowego (w edukacji formalnej $6 \%$, w pozaformalnej 38\%) (Stec i in. 2018). Podobne rozbieżności pojawiają się także w badaniach międzynarodowych (Goglio, Meroni 2014; Rubenson 2019).

Obserwowane niespójności do pewnego stopnia wyjaśnić można różnym grupowaniem aktywności edukacyjnych czy też wyodrębnianiem wśród nich podkategorii ze względu na obszar, którego nauka dotyczy. Na przykład w Bilansie Kapitału Ludzkiego oddzielnie zadane zostało pytanie o uczenie się pozaformalne w związku z aktywnością zawodową, a oddzielnie o uczestnictwo w kursach i szkoleniach niezwiązanych z pracą; z kolei w badaniu Kształcenie Dorostych obszary te są połączone. Analizy prezentowane w literaturze wskazują, że potencjalnych przyczyn występowania rozbieżności w wynikach jest więcej. Wymienić wśród nich można choćby odmienne sposoby formułowania pytań, różnice w strukturze i stopniu złożoności narzędzi badawczych, inny zakres działań edukacyjnych uwzględniony $\mathrm{w}$ badaniach czy niejednakowe procedury gromadzenia danych (zob. Desjardins 2014; Goglio, Meroni 2014). 


\section{Jakość pomiaru}

Odpowiedzi na pytanie o to, które informacje na temat poziomu uczestnictwa osób dorosłych w edukacji - zwłaszcza pozaformalnej i nieformalnej-najlepiej ukazują rzeczywisty poziom tego zjawiska, poszukiwać można w analizach trafności pomiaru prowadzonego z wykorzystaniem poszczególnych pytań, skal czy całych narzędzi badawczych. W niniejszym artykule przyjęto, iż dążenie do uzyskania wskaźników o jak najwyższej trafności - co $\mathrm{w}$ rezultacie prowadzić ma do zminimalizowania błędu pomiaru ${ }^{4}$ - oraz dbałość o komfort osoby badanej są kluczowymi aspektami zapewniania wysokiej jakości pomiaru. Za najważniejsze działanie, prowadzące do jej osiągnięcia, uznano więc uważne przyjrzenie się perspektywie respondenta. Dokonując jej analizy, dążono do zidentyfikowania w pytaniach kwestionariusza zwrotów, których stosowanie, na przykład ze względu na rozbieżności między perspektywą badacza i badanego lub z uwagi na nieneutralny z punktu widzenia respondenta charakter, może w sposób systematyczny wpływać na wyniki, a tym samym zwiększać błąd pomiaru. Założono ponadto, że poświęcenie uwagi problemowi drażliwości pytań może wspomagać polepszanie jakości pomiaru w dwóch, w dużej mierze przenikających się, wymiarach. $Z$ jednej strony służy poprawie jakości uzyskiwanych wskaźników. Przyjęto bowiem, że reakcja emocjonalna na pytanie może prowadzić do ukierunkowania się respondenta na poradzenie sobie z sytuacją badawcza, na przykład poprzez udzielenie jakiejkolwiek lub antycy powanej jako społecznie akceptowalnej odpowiedzi, zamiast przekazania informacji o faktycznie podejmowa-

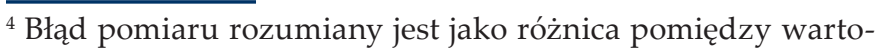
ścią estymatora pewnego parametru, ustaloną na podstawie badania, a prawdziwą wartością tego parametru w całej populacji (Biemer 2010: 817-818 za: Jabkowski 2015: 23). nych działaniach. Z drugiej strony redukowanie poziomu drażliwości pytań traktowano, co oczywiste, jako wspomagające realizację badania zgodnie z zasadami etyki. Analizom w tym obszarze przyświecała więc troska o komfort respondenta, wykraczająca poza dążenie do uzyskania trafnych wskaźników. Bez względu na to, czy w danym przypadku przewidywano, czy też nie, iż samopoczucie osoby badanej przełożyć może się na udzielane przez nią odpowiedzi, dokładano wszelkich starań, by, w oparciu o wnioski z pilotażu, pytania korygować tak, aby były jak najmniej obciążające dla respondenta.

\section{Błędy pomiaru}

Dążąc do zmniejszania błędów pomiaru, w prezentowanych w niniejszym artykule analizach przyjmowana jest, zależnie od specyfiki pytań, tak zwana statystyczna bądź psychologiczna, czy inaczej psychometryczna, koncepcja wartości prawdziwej, rozumianej jako wartość ukazująca stan faktyczny (zob. Sztabiński 2011). Oznacza to, że w przypadku niektórych pozycji kwestionariusza (zwłaszcza chodzi tu o pytania dotyczące podejmowania aktywności edukacyjnych), zgodnie z ujęciem statystycznym, zakłada się, iż wartość prawdziwa parametru populacyjnego rzeczywiście istnieje. Co z tym związane, przyjmuje się, że możliwe jest uzyskanie od respondentów informacji na temat rzeczywistych wartości cech - na przykład danych o faktycznie podejmowanych przez nich działaniach. W innych sytuacjach, przy pozycjach odnoszących się do postaw i opinii, w spójności z ujęciem psychologicznym, nie czyni się założenia o rzeczywistym istnieniu prawdziwej wartości zmiennej w populacji.

Przyglądając się pozycjom kwestionariusza wywiadu z badania Uczenie się dorostych Polaków, wskazać można aspekty, których dopracowywanie służy 
minimalizowaniu zarówno błędu psychologicznego, jak i statystycznego. Są to kwestie o charakterze uniwersalnym dla badań sondażowych, takie jak: posługiwanie się zrozumiałym dla respondentów językiem, stosowanie takich zwrotów i takiego sposobu zestawiania pytań, które w możliwie najmniejszym stopniu narażałyby osobę badaną na dyskomfort, a także taką konstrukcję kafeterii/ skal odpowiedzi, by nie tylko miały one charakter wyczerpujący i rozłączny, ale by czyniły proces udzielania odpowiedzi jak najbliższy intuicyjnemu. Charakter omawianego tu badania pozwala jednak także na wskazanie dla każdego z ujęć specyficznych działań wspomagających zmniejszanie błędu pomiaru. I tak, w sytuacjach, w których redukcja błędu zmierzać ma do poprawnego oszacowania wartości prawdziwej zjawiska, na przykład poziomu uczestnictwa w uczeniu się, szczególnie istotnym wydaje się być dobór pojęć używanych do opisu interesujących badaczy kategorii, a także wyraźne określenie horyzontu czasowego, do którego odpowiadający powinien się odnieść. Z kolei w dążeniu do minimalizowania błędu psychologicznego, czy też psychometrycznego, za kluczowe uznać należy takie formułowanie pytań, by w jak najmniejszym stopniu sugerowały one badanym istnienie właściwych lub błędnych odpowiedzi, a możliwie jak najbardziej zachęcały do wyrażenia własnych odczuć, ocen, myśli i opinii. W badaniach nad uczeniem się dorosłych takie działania polegać mogą na przykład na eliminowaniu stwierdzeń przywodzących na myśl utarte frazesy na temat znaczenia edukacji i płynących z niej korzyści.

\section{Drażliwość pytań}

Jak wskazywane było wyżej, na odpowiedzi respondentów wpływa nie tylko sposób rozumienia i interpretacji użytych przez badacza terminów, ale również reakcje emocjonalne wywoływane przez pytania. Wywiad nie jest naturalną rozmową, szeroko w literaturze opisywane są zjawiska dotyczące wpływu samej sytuacji wywiadu, interakcji z osoba, która go prowadzi, jak: efekt społecznych oczekiwań czy efekt ankieterski. Istotnym problemem metodologiczno-etycznym badań kwestionariuszowych jest drażliwość. Jak pisali Anna Kubiak, Ilona Przybyłowska i Andrzej Rostocki, definiowana jest jako: „cecha pytania, która wywołuje w respondencie negatywne procesy emocjonalne (wstyd, zażenowanie, lęk, gniew, złość itp.)” (1992: 97). Może być spowodowana: zbyt dużą trudnością pytania, naruszeniem sfery prywatności i intymności, zawartymi w nim nieobojętnymi treściami. Negatywne odczucia, poczucie niedopasowania, bycia gorszym, wstyd związany z niezrozumieniem pytania czy własną sytuacją wiążą się z ryzykiem unikania odpowiedzi przez respondentów, podawania odpowiedzi niezgodnych z prawdą czy w przypadku kumulacji negatywnych emocji, wycofaniem zgody na realizację wywiadu. Analizy odnoszące się do okresu PRL-u i następnie do lat 90. pokazują, że jednym z trzech kluczowych obszarów powiązanych z problemem drażliwości w badaniach społecznych są pytania o wykształcenie, czytelnictwo i udział w życiu kulturalnym (Lutyńska 2000). Zarysowane przez Krystynę Lutyńską obszary z dzisiejszej perspektywy można jeszcze uzupełnić o model człowieka będącego na bieżąco, nadą̇ającego za nowoczesnościa czy też nastawionego na rozwój. Cechy te promowane są jako wzorce kulturowe zarówno w przekazie instytucjonalnym, jak i dyskursie publicznym. Dla respondenta, który nie jest aktywny edukacyjnie, szczególnie jeśli brak aktywności w tym zakresie współwystępuje z pozostawaniem poza rynkiem pracy, przejście przez kwestionariusz koncentrujący się wokół tych zagadnień może być bardzo obciążające. 
Dążenie do ograniczenia poziomu drażliwości poszczególnych pytań jest zarówno związane z chęcią sprostania wymaganiom etycznym stojącym przed badaczami, jak również metodologicznym - związanym $\mathrm{z}$ osiąganiem trafnych i wiarygodnych wyników. Może zostać zrealizowane poprzez unikanie słów czy zagadnień wywołujących negatywne emocje, trudne wspomnienia czy poczucie wstydu, bycia gorszym. Jasne jest, że nie da się w pełni wyeliminować takiego ryzyka, każdy z respondentów ma swoje własne doświadczenia i nie jesteśmy w stanie przewidzieć wszystkich możliwych źródeł naruszenia jego komfortu. Jednakże zamiana potencjalnie drażliwych sformułowań czy rezygnacja z pytań wywołujących zakłopotanie jest działaniem wynikającym zarówno z dbałości o respondenta, jak i jakość uzyskiwanych danych.

\section{Wywiad kognitywny - ramy metodologiczne i zastosowanie}

W odpowiedzi na przedstawione wyżej problemy zdecydowano się na zrealizowanie pierwszego etapu pilotażu z wykorzystaniem metody wywiadów kognitywnych (ang. cognitive interviewing). Jej celem jest weryfikacja, a w konsekwencji zwiększenie prawdopodobieństwa, że respondent zrozumie pytanie kwestionariuszowe w sposób zgodny z intencją badacza (Tourangeau, Bradburn 2010). Istotnym wyróżnikiem zastosowanego podejścia jest możliwość uchwycenia zachodzących $\mathrm{u}$ respondenta procesów poznawczych poprzez udzielanie przez niego szerszego wachlarza informacji niż sama odpowiedź na pytanie (Grzeszkiewicz-Radulska 2012). Koncentracja na samej odpowiedzi jest bowiem niewystarczająca do prawidłowego zaprojektowania narzędzia, gdyż jej sformułowanie jest zaledwie efektem końcowym procesu poznawczego (Van Someren, Barnard,
Sandberg 1994). Składają się na niego: zrozumienie pytania, przypomnienie sobie informacji potrzebnych do udzielenia odpowiedzi oraz ocena tychże informacji i ocena stopnia, w jakim respondent chce je ujawnić badaczowi. Jednocześnie każdy z tych elementów potencjalnie obarczony jest błędem - pytanie może zostać źle zinterpretowane czy być wieloznaczne, podobnie jak sformułowana przez badanego odpowiedź. Zdolność do zapamiętywania i przypominania również posiada pewne ograniczenia, co w przypadku pytań z kafeterią odpowiedzi znajduje odzwierciedlenie na przykład w częstszym wyborze pozycji z początku lub końca listy (efekt pierwszeństwa i efekt świeżości, zob. Lavrakas 2008). Wyrażane w badaniu motywacje, przyczyny czy uzasadnienia formułowane są natomiast zazwyczaj retrospektywnie, co oznacza, że dana sytuacja postrzegana może być przez pryzmat późniejszych jej konsekwencji (Tourangeau 1984). Istotne są także różnice indywidualne, będące przedmiotem zainteresowania psychologów. Dokonywanie i prezentowanie oceny swoich motywacji i wyborów zależeć może bowiem nie tylko od poziomu samoświadomości jednostki, ale także na przykład od jej temperamentu, samooceny lub dominującego stylu atrybucji.

Wyróżnia się dwa sposoby realizowania wywiadów kognitywnych: technika myślenia na głos (ang. thinking aloud) oraz technika pytań pogłębiających, określana jako sondowanie (ang. verbal probing). W ramach formuły aranżacyjnej pierwszej techniki respondent zostaje zapoznany z instrukcją, by po usłyszeniu pytania werbalizować swoje myśli poprzedzające sformułowanie odpowiedzi. Oznacza to, że badany „na głos” przywołuje swoje wspomnienia i dokonuje wyboru, zanim przekaże końcową odpowiedź. Następnie przeprowadzane jest krótkie ćwiczenie obrazujące sposób postępo- 
wania. Rola osoby prowadzącej wywiad jest tutaj sprowadzana do koniecznego minimum - w zależności od potrzeb i decyzji projektującego narzędzie badawcze może ona notować trop, którym podąża badany $\mathrm{w}$ ramach swojej rozbudowanej odpowiedzi (gdy wywiad jest nagrywany, to notatki te mogą mieć charakter dodatkowej pomocy), lub nie angażować się w rozmowę z respondentem w inny sposób niż tylko odczytywanie pytań z kwestionariusza. Technika pytań pogłębiających zakłada natomiast zaangażowanie osoby prowadzącej wywiad $w$ wypowiedzi respondenta i rozwijanie ich poprzez dopytywanie, to znaczy zadawanie dodatkowych pytań o większym poziomie szczegółowości. Mogą one być zarówno wskazane w narzędziu badawczym, jak i stanowić bieżącą reakcję na wypowiedzi badanego - zwłaszcza w przypadku pojawienia się nowych czy niejednoznacznych terminów, wymagających doprecyzowania (Liani, Martire, Pitrone 2015). Możliwość takiego podążenia za rozmówcą $\mathrm{w}$ podejściu verbal probing przywodzi na myśl skojarzenia z indywidualnym wywiadem pogłębionym.

Każde z opisanych wyżej podejść (thinking aloud oraz verbal probing) pozwala na uzyskanie innego zakresu informacji, na przykład w przypadku myślenia na głos informacje mogą być mniej szczegółowe lub mieć węższy zakres. Oba te elementy zależą bowiem od stopnia otwartości respondenta oraz jego umiejętności werbalizowania swoich myśli, a osoba prowadząca wywiad nie ma możliwości ukierunkowania, ani pogłębienia odpowiedzi badanego. Skuteczność thinking aloud i verbal probing w wywiadzie kognitywnym jest również zależna od odpowiedniego dopasowania ich do testowanych pytań (Priede, Farrall 2010) oraz celów badania. I chociaż początkowo uznawano te techniki za oddzielne podejścia, jednocześnie dostrzegając wyższość son- dowania nad myśleniem na głos, obecnie łączy się je celem uzyskania szerszego zakresu informacji przydatnych do projektowania narzędzia (Willis 2005). Takie połączenie, nazywane modelem hybrydowym, stosowano już zarówno w badaniach edukacyjnych (Sopromadze, Moorosi 2016), jak i w innych dziedzinach, na przykład w opiece zdrowotnej (Ciccolo i in. 2020). Wskazywane różnice pomiędzy teoretycznym rozróżnieniem obu technik a rzeczywistością wywiadu badawczego i procesami zachodzącymi u respondenta w praktyce nie okazują się wykluczające (Ryan, Gannon-Slater, Culbertson 2012). W przypadku zastosowania przez badacza wyłącznie techniki verbal probing badani i tak „myślą na głos", chociaż przebiega to w inny sposób niż wtedy, gdy są o to proszeni wprost (DeMaio, Landreth 2004 za: Ryan i in. 2012).

\section{Wywiad kognitywny jako pierwszy etap pilotażu badania uczenia się osób dorosłych}

W pilotażu kwestionariusza wywiadu do badania Uczenia sie dorostych Polaków wywiad kognitywny połączony został z elementami jakościowego wywiadu pogłębionego (dalej także: IDI - individual in-depth interview). Założono, że pozwoli to na zidentyfikowanie i wyeliminowanie pierwszych, dostrzeganych jeszcze przed ilościowym pilotażem potencjalnych problemów i niejasności, zarówno na podstawie lepszego zrozumienia procesów poznawczych respondentów, jak i poznania ich perspektywy na zjawisko uczenia się w dorosłości. Cały kwestionariusz ankiety zostanie przetestowany w ramach drugiej, ilościowej części badania pilotażowego.

Zagadnienie liczebności próby w badaniach kognitywnych jest złożonym problemem, nie jest możliwe 
udzielenie jednoznacznej odpowiedzi, ile wywiadów należy zrealizować. Według Gordona Willisa (2015) można wskazać różne podejścia: począwszy od realizacji takiej liczby wywiadów, na jaką pozwalają zasoby - jakiekolwiek testowane jest lepsze niż żadne, poprzez oparte na zaleceniach jakościowych - realizacja do wysycenia, aż wreszcie statystyczny dobór analogiczny do metod ilościowych. Autor podaje przykłady badań, w których kontakt z kilkorgiem rozmówców pozwolił ustalić najważniejsze sugestie dotyczące zadawanych pytań, jak i pilotaży z grupami kilkudziesięciu respondentów.

W ramach omawianego etapu pilotażu próba liczyła 12 respondentów dobranych w sposób celowy. Wywiady zostały rozłożone równomiernie pomiędzy kategoriami różnicującymi badaną populację po jednym w każdym przedziale wiekowym (wiek produkcyjny, tj. 25-64 lata, w przedziałach co 10 lat), dla każdego poziomu wykształcenia (podstawowe lub gimnazjalne, lub zasadnicze zawodowe; średnie lub policealne; wyższe), a także pod względem płci. Próba została zróżnicowana również ze względu na kryterium doświadczenia w zakresie uczenia się $\mathrm{w}$ dorosłości. Założono realizację co najmniej 6 wywiadów z osobami, które w ciągu ostatnich 3 lat uczestniczyły $\mathrm{w}$ przynajmniej jednej z trzech form uczenia się $\mathrm{w}$ okresie dorosłości: uczeniu się formalnym, pozaformalnym lub nieformalnym - rozłożone proporcjonalnie pomiędzy poziomy wykształcenia. W ten sposób zapewniono w badaniu pilotażowym uwzględnienie perspektywy osób podejmujących aktywność edukacyjną w dorosłości. Wywiady odbywały się w sali focusowej, umożliwiając badaczom bieżącą obserwację ich przebiegu.

Projektując scenariusz do realizacji wywiadów, zdecydowano się zastosować nieklasyczne, omó- wione już podejście hybrydowe do wywiadu kognitywnego - połączono podejścia thinking aloud oraz verbal probing $\mathrm{w}$ ramach jednego wywiadu i jednego narzędzia. Do scenariusza dodano również pytania charakterystyczne dla techniki pogłębionego wywiadu indywidualnego (IDI). Zakładano, że umożliwi to nie tylko poznanie ścieżki respondenta $\mathrm{w}$ docieraniu do odpowiedzi, trudności w przypominaniu sobie faktów i rozumieniu pytań, ale również umożliwi między innymi weryfikację kompletności kafeterii czy poznanie sposobu rozumienia wybranych pojęć używanych w projektowanym kwestionariuszu. Natomiast pogłębienie tematyki uczenia się w dorosłości oraz doświadczeń respondentów miało z kolei przybliżyć język, jakim posługują się badani, ich percepcję zjawiska oraz zidentyfikować zakresy znaczeniowe wybranych terminów. Na podstawie rozpoznanych podobieństw i różnic pomiędzy wynikami uzyskanymi z pilotażu a definicjami przyjętymi przez badaczy możliwe będzie stworzenie bardziej zrozumiałych i precyzyjnych pytań ilościowych do kwestionariusza wywiadu - co jest zgodne z celem realizacji wywiadów kognitywnych (Willis 2018). Połączenie podejść i technik stanowiło odpowiedź na zróżnicowane problemy dotyczące badania uczenia się w dorosłości - ograniczenie do jednej z nich nie pozwoliłoby na uzyskanie wystarczających, w opinii badaczy, danych.

Przygotowując się do realizacji wywiadów kognitywnych, stworzono scenariusz wywiadu zawierający wybrane pytania $\mathrm{z}$ kwestionariusza (na podstawie antycypowanych przez badaczy problemów) oraz pytania jakościowe - zarówno sondujące, jak i pogłębiające. Za zastosowaniem takiego rozwiązania stały dwa argumenty istotne z metodologicznego punktu widzenia. Po pierwsze, konieczność sprawdzenia pytań ankietowych 
pod kątem określonych dla każdego z nich potencjalnych problemów, takich jak na przykład: intersubiektywność stwierdzeń, kompletność i zrozumiałość zaproponowanej kafeterii odpowiedzi, zrozumiałość aranżacji pytania czy opisu skali. Po drugie, potrzeba realizacji wywiadów w sposób niewytrącający respondenta $\mathrm{z}$ sytuacji rozmowy, z jakiej czerpie swoje korzenie pogłębiony wywiad indywidualny. W konsekwencji pytania ankietowe zamieszczono w scenariuszu na dwa sposoby. W zależności od celu weryfikacji zadawano je wraz $\mathrm{z}$ kafeterią odpowiedzi lub też $\mathrm{w}$ formie pytania otwartego. W niektórych przypadkach, po spontanicznej odpowiedzi respondenta na pytanie zadane jako otwarte, przedstawiano kartę, na której zamieszczono proponowaną kafeterię odpowiedzi i pytano respondenta, czy ten odnajduje swoją odpowiedź wśród zaproponowanych.

Podejście thinking aloud wprowadzono do scenariusza, poprzedzając pytania ankietowe prośbą do respondenta, by udzielając odpowiedzi,,,myślał na głos" i na bieżąco opowiadał, nad czym się zastanawia, zanim wskaże swój wybór (zob. np. Ryan $i$ in. 2012). Aby zapoznać osoby badane $z$ tą techniką, na początku wywiadu wprowadzono krótkie ćwiczenie: przedstawiano przykład docierania do odpowiedzi z zastosowaniem zasady,"głośnego myślenia", wykorzystując pytanie odnoszące się do sytuacji codziennej. Następnie proszono badanego, by w analogiczny sposób odpowiedział na podobnego typu pytanie. Podejście „myślenia na głos” wykorzystano między innymi w pytaniach, w których respondent określał, w jakim stopniu zgadza lub nie zgadza się z przedstawionymi stwierdzeniami lub też, na ile odnoszą się one do jego sytuacji. Natomiast podejście verbal probing stosowano $\mathrm{w}$ formie pytań sondujących, na przykład: Jak P. rozumie... [pojęcie/zwrot]?, zadawanych bezpośrednio po udzie- leniu odpowiedzi na pytanie ankietowe. Przy niektórych pytaniach respondent był również proszony o to, by własnymi słowami opowiedział, czego one dotyczyły. Ponadto wykorzystywano nie tylko pytania sondujące, ale także pogłębiające, pozwalające lepiej zrozumieć perspektywę badanych na kwestię poruszoną w pytaniu. Scenariusz zawierał również pytania będące nawiązaniem do innych zagadnień z kwestionariusza wywiadu, jednak niepowiązanych bezpośrednio z zagnieżdżonym w nim pytaniem ankietowym. Ich celem było uzyskanie odpowiedzi o charakterze jakościowym na bardziej ogólnym poziomie. W założeniu miało to pozwolić na poznanie sposobu myślenia respondentów na temat badanego zjawiska oraz uchwycić ich sposób narracji na ten temat. Natomiast dalsza eksploracja tego obszaru była możliwa głównie dzięki zastosowaniu zróżnicowanych rozwiązań na poziomie pytań, to znaczy wykorzystanie wszystkich trzech sposobów dotarcia do odpowiedzi (poprzez thinking aloud, verbal probing oraz elementy pogłębionego wywiadu IDI) w ramach scenariusza.

Metoda jakościowa dopuszcza pewien stopień elastyczności przy gromadzeniu danych - pytania do pewnego stopnia mogą być modyfikowane przez badacza przy zachowaniu ich celu i sensu, dopuszcza się także zmianę kolejności ich zadawania. Zdecydowano więc o wprowadzaniu modyfikacji do scenariusza w trakcie trwania badania. Drugim argumentem przemawiającym za tą decyzją były ograniczenia wynikające z założonych kosztów całego projektu badawczego poświęconego uczeniu się dorosłych. Proces badawczy nie uwzględniał prepilotażu, co oznacza, że nie zweryfikowano wcześniej pytań scenariusza. O potrzebie zmian rozstrzygali badacze na podstawie bieżącej analizy komunikatów werbalnych respondentów, a także wysyłanych przez nich sygnałów niewerbalnych. 
Największe zmiany miały miejsce po realizacji pierwszych czterech wywiadów, w których brali udział respondenci o zróżnicowanych cechach społeczno-demograficznych. Scenariusz przede wszystkim skrócono - także ze względu na znacząco przedłużający się czas trwania wywiadów. Usunięto z niego pytania, które:

1. były zrozumiałe dla respondentów oraz interpretowane przez nich jednakowo i zgodnie $\mathrm{z}$ intencją badaczy,

2. były niezrozumiałe dla respondentów lub każdy zrozumiał je inaczej lub rozumiano je w sposób niezgodny $\mathrm{z}$ intencją badaczy - co pozwoliło stwierdzić, że pytanie lub zwrot jednoznacznie wymagają przeformułowania, nie ma zatem potrzeby jego dalszego weryfikowania,

3. stanowiły interesujący wgląd w doświadczenia respondentów, prowokowały jednak do zbyt daleko posuniętego pogłębiania wątków, przy jednocześnie mniejszej użyteczności realizacji założonych celów pierwszego etapu pilotażu,

4. stanowiły kontynuację lub pogłębienie wątku lub pytania usuniętego ze względu na jedno z powyższych kryteriów.

Pytania, w których zaobserwowano, że sprawiają respondentom trudność $\mathrm{w}$ udzielaniu odpowiedzi, uzupełniono o instrukcję, w jaki sposób respondent powinien udzielać odpowiedzi. Dodano na przykład zwrot na następne pytanie proszę odpowiedzieć tak lub nie. Wprowadzono równomiernie rozłożone pomiędzy wywiadami wariantowanie brzmienia pytania - połowie respondentów zadawano pytanie $\mathrm{w}$ jednym brzmieniu, a połowie respondentów w drugim. Zamieszczono również wskazówki dla osoby prowadzącej wywiad dotyczące sposobu prowadzenia wywiadu kognitywnego, na przykład wskazujące na odczytywanie pytania zawartego $\mathrm{w}$ tabeli wierszami, a nie kolumnami. Zdecydowano się także zadawać niektóre pytania wszystkim respondentom poprzez usunięcie znajdujących się przed nimi pytań filtrujących. Miało to umożliwić uzyskanie szerszego zakresu danych. Przykładem takiej zmiany może być pytanie Jak P. rozumie zwrot "przerwać naukę w szkole"?, które pierwszego dnia realizacji wywiadów zadawano wyłącznie osobom, które z jakiegoś powodu przerwały naukę w szkole.

W toku kolejnych dwóch dni realizacji wywiadów kognitywnych, na podstawie ich bieżącej analizy, zdecydowano się na wprowadzenie niedużych zmian do scenariusza. Dotyczyły one brzmienia pytań ankietowych, w których dostrzeżono na przykład potrzebę zmian $\mathrm{w}$ wykorzystywanych zwrotach czy określeniach oraz w opisie skali. Modyfikacje zwrotów nie zmieniały zasadniczego sensu i znaczenia dla rozumienia pytania, zmniejszały natomiast obserwowane zmieszanie lub dyskomfort badanego (szerzej zagadnienie to omówiono $\mathrm{w}$ dalszej części artykułu). Pierwotne brzmienie opisu skali okazało się nieadekwatne, gdyż respondenci nie używali zawartych $\mathrm{w}$ niej zwrotów. Usunięto jedno z pytań, które po wprowadzonej wcześniej modyfikacji brzmienia stało się dla respondentów jednoznaczne, nie było zatem potrzeby jego dalszego testowania.

Zastosowanie zmian w konstrukcji scenariusza stanowiło odpowiedź na pojawiające się na bieżąco potrzeby, a zarazem pozwoliło na uzyskanie szerszego zakresu danych niż pierwotnie zakładano. Wprowadzone modyfikacje pozwoliły zweryfikować kierunek zmian i wyznaczyć sposób projektowania adekwatnego narzędzia w badaniu głównym. 


\section{Analiza wyników wywiadów kognitywnych}

\section{Pomiar poziomu uczestnictwa dorosłych w uczeniu się}

W kontekście planowanego badania Uczenia się dorostych Polaków, podczas wywiadów kognitywnych, dążąc do redukcji statystycznego błędu pomiaru, w szczególności skupiono się na doprecyzowaniu brzmienia pytań mierzących poziom uczestnictwa w różnych formach edukacyjnych. Uwzględnienie w tej części pilotażu pytań o udział w edukacji pozaformalnej miało przede wszystkim zmierzać do zapewnienia kompletności i zrozumiałości poszczególnych kategorii kafeterii odczytywanej respondentowi. W toku swobodnej rozmowy na temat możliwych sposobów kształcenia badani nie rozszerzyli jej zakresu poza pierwotnie przyjęty, co pozwoliło uznać, że kryterium to zostało spełnione. Zauważono natomiast, że nie wszystkie terminy są zrozumiałe i nie wszystkie definiowane są przez badanych w ten sam sposób. Różnorodność doświadczeń edukacyjnych i zawodowych respondentów skłoniła do ponownego przeanalizowania znaczenia każdej kategorii, a w konsekwencji do podjęcia szeregu zmian.

Podczas omawiania różnic między kursami i szkoleniami a warsztatami część badanych poprowadziła linię demarkacyjną pomiędzy znaczeniami tych słów, wskazując na teoretyczny wymiar pierwszych i praktyczny wydźwięk drugiej formy kształcenia. W przypadku respondentów związanych zawodowo z branżami wymagającymi między innymi umiejętności technicznych granica ulegała zatarciu, a zdobycie wiedzy teoretycznej ściśle wiązało się z wykorzystaniem jej w praktyce. W takiej sytuacji respondenci wybierali pierwszą odpowiedź na liście, czyli kursy, szkole- nia, a następnie trzecią $\mathrm{w}$ kolejności, czyli warsztaty, zwiększając tym samym swój deklarowany udział w aktywnościach edukacyjnych do dwóch różnych form, mimo realnie posiadania jednego doświadczenia. Ostatecznie zredukowano dwie kategorie kursy, szkolenia - stacjonarne oraz warsztaty do jednej: kursy, szkolenia, warsztaty - stacjonarne, nie przez Internet. Doprecyzowano także określenie stacjonarnie, które niezgodnie $\mathrm{z}$ intencją $\mathrm{w}$ jednostkowych przypadkach rozumiane było jako szkolenie wyjazdowe albo szkolenie, które trwa dłużej, od kilku tygodni do kilku miesięcy. Analogiczną zmianę wprowadzono, rezygnując $\mathrm{z}$ wyodrębniania udziału $\mathrm{w}$ konferencjach, odczytach, prelekcjach i innych spotkaniach, zamieniając cztery osobne itemy na jedną kategorię: konferencje, odczyty, prelekcje, spotkania tematyczne. Skracając kafeterię, kierowano się potrzebą uproszczenia procesu udzielania odpowiedzi, zwłaszcza odpowiedniego szacowania podejmowanych aktywności i raportowania, to jest odwzorowywania ich na znajdujące się w kwestionariuszu kategorie (Groves i in. 2004).

Zmiany wprowadzono także w zakresie liczby zadawanych pytań mierzących uczestnictwo w edukacji pozaformalnej. Pierwotnie planowano odczytać respondentom dwa, podobnie jak w przypadku Bilansu Kapitału Ludzkiego, prosząc najpierw o przypomnienie sobie aktywności związanych z praca, a następnie o przywołanie z pamięci działań podejmowanych $z$ zamiarem uczenia się, zdobywania wiedzy poza sfera zawodowa, dotyczacych zainteresowań, hobby, własnego rozwoju. Takie podejście jest też zgodne $\mathrm{z}$ aktualnymi tendencjami do wzmacniania przekazu o uczeniu się w innych kontekstach - nie tylko zawodowym (Rubenson 2019). W trakcie wywiadów kognitywnych badani mieli jednak problem z jednoznacznym określeniem celu realizowanych działań edukacyjnych - niektórzy nie potrafili 
wskazać, czy zostały one podjęte z myślą o pracy zawodowej, czy na skutek zainteresowań pozazawodowych. Prowadziło to do dublowania odpowiedzi lub błędnego przypisania ich do właściwego obsza$\mathrm{ru}, \mathrm{a} \mathrm{w}$ konsekwencji - rodziło ryzyko uzyskania nietrafnych wyników. Dążąc do zmniejszenia statystycznego błędu pomiaru, ale także, aby uniknąć nadmiernego obciążania respondenta, przy jednoczesnym zachowaniu odpowiedniego poziomu szczegółowości, zdecydowano się zadać jedno pytanie o aktywność w edukacji pozaformalnej, niezależnie, czy dotyczy pracy zawodowej, czy nie. Aby wspomóc pamięć respondenta, kafeterię odpowiedzi uzupełniono o komentarze mające na celu ułatwienie przywołania określonych wspomnień. Wprowadzono także dodatkowe pytania - już poza wskaźnikiem uczenia się w dorosłości - pozwalające lepiej zrozumieć kontekst podejmowanych działań edukacyjnych, między innymi zakres tematyczny czy częstotliwość podejmowania aktywności.

Kwestia znaczenia terminów okazała się istotna również $\mathrm{w}$ zakresie formułowania pytań o uczenie się nieformalne. Zaobserwowano, że badani wykazywali tendencję do rozszerzania definicji samodzielnego uczenia się o działania nieintencjonalne. Mimo wyraźnego podkreślenia w treści pytania celowości towarzyszącej uczeniu się nieformalnemu poprzez użycie zwrotu po to, żeby zdobyć umiejętności, wiedzę, nauczyć się czegoś, badani z łatwością przechodzili od działań edukacyjnych do aktywności edukujacych.

\section{$\mathbf{B}^{5}$ : Telewizyjnych i radiowych też? \\ R: No tak. Od członków rodziny z zupełnie innymi... tak, też. Uczyłam się od znajomych, tak. Podczas spo- tkań, jak najbardziej, kółka, w klubie. Wizyt w muze-}

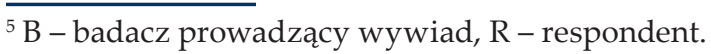

ach, galeriach, centrach naukowych, jak najbardziej, ten... Centrum Kopernika.

B: OK.

R: Uczyłam się w inny sposób. Ja nie wiem, w jaki inny, nie wiem.

B: Aha, a w jakiś inny, który tu został wymieniony? Jeszcze przychodzi do głowy coś, czy...?

R: No nie wiem.

B: Czy jeszcze jakiś inny?

R: [zastanawia się] No nie wiem, jaki inny... krzyżówki rozwiązywałam. [W. 1]

Dążąc do utrzymania uwagi respondentów na pełnej treści pytania, a tym samym do posługiwania się definicją uczenia się przyjętą w badaniu, sformułowano kategorie odpowiedzi w pierwszej osobie, podkreślając przy tym samodzielność podejmowanych działań. $W$ rezultacie dotychczasowe określenia, na przykład: uczenie się z książek, czasopism lub innych materiałów drukowanych zostało zastąpione odpowiedzią uczył(a) się Pan(i) samodzielnie z ksiażek, czasopism lub innych materiatów drukowanych. Odciążono również percepcję respondentów, dzieląc obszerną listę możliwych form kształcenia nieformalnego na dwa pytania - uczenie się wspierane materiałami zastanymi oraz uczenie się w interakcji z innymi osobami.

\section{Badanie postaw względem uczenia się w dorosłości}

Poza pomiarem uczestnictwa w edukacji osób dorosłych jednym z najważniejszych celów badania jest dokonanie analizy postaw wobec uczenia się w dorosłości. Definicja postawy została zaczerpnięta z książki Stefana Nowaka (1973). Według niej przyjmuje się, że:

postawą pewnego człowieka wobec pewnego przedmiotu jest ogół względnie trwałych dyspozycji do 
oceniania tego przedmiotu i emocjonalnego nań reagowania oraz ewentualnie towarzyszących tym emocjonalno-oceniającym dyspozycjom względnie trwałych przekonań o naturze i właściwościach tego przedmiotu i względnie trwałych dyspozycji do zachowania się wobec tego przedmiotu. (Nowak 1973: 23)

Definicja zawiera wszystkie najważniejsze aspekty w badaniach postaw: odwołuje się do doświadczeń behawioryzmu oraz badań nad motywacjami tychże, wydobywa element związany z przekonaniami podmiotu i dokonywaną przez niego oceną, wreszcie, odwołuje się do emocji. Każdy z nich został uwzględniony $\mathrm{w}$ stwierdzeniach zamieszczonych w kwestionariuszu, na przykład: W każdym wieku uczenie się ma sens, Uczenie się w dorostości to inwestowanie w siebie, Uczenie się jest dla dzieci i młodzieży, a nie dla dorostych, Gdy sie jest dorostym, uczenie nie przynosi korzyści, Pieniadze wydane na uczenie się w dorosłości to pieniadze dobrze wydane. Projektując je, przyjęto, że ogólne sformułowania będą dla badanych lustrem, w którym odbiją się ich różnorodne doświadczenia i przekonania, do których badacze uzyskają wgląd, stosując technikę „myślenia na głos”. Podczas wywiadu kognitywnego respondenci, posługując się skalą Likerta, mieli określić, w jakim stopniu zgadzają się z poszczególnymi zdaniami oraz uzasadniać swoją ocenę. Dodatkowo zakres zebranych danych został rozszerzony poprzez zadanie pytań pogłębiających percepcję zjawiska uczenia się w dorosłości.

Badani, odwołując się do swoich doświadczeń edukacyjnych, zwracali uwage na pragmatyczny wymiar uczenia się. We wspomnieniach powracali często do sytuacji związanych z pracą zawodową, koncentrując się na wymiernych korzyściach towarzyszących nabywaniu wiedzy i umiejętności, takich jak: dostosowanie się do zmieniających się wy- mogów pracodawców, wzmocnienie swojej pozycji na coraz bardziej konkurencyjnym rynku pracy, możliwość rozwoju ścieżki zawodowej i poprawy aktualnych warunków zatrudnienia. Podkreślono przede wszystkim efekt końcowy, a nie sam proces uczenia się - to, co dzięki nabyciu wiedzy, a przede wszystkim możliwości wykorzystania jej w praktyce, można osiągnąć. Spójny z rynkową perspektywą na działania edukacyjne był prowadzony równolegle wątek dotyczący indywidualnego podejścia do procesów uczenia się: począwszy od samodzielnego podejmowania decyzji o (nie)podjęciu nauki, przez wybór formy kształcenia (samodzielna nauka wspierana innymi metodami nieformalnymi), aż do jednostkowych beneficjentów podjętych działań (czyli tych, którzy zdecydowali się rozpocząć naukę). Jednakże badani w obliczu pytań o postawę sięgają nie tylko do pamięci epizodycznej, która pozwala im przywołać własne doświadczenia i wspomnienia dotyczące działań edukacyjnych. Analiza ich wypowiedzi prowadzi do wniosku, że równie często aktywowana jest pamięć semantyczna (Ryan $i$ in. 2012).

Stwierdzenia dotyczące uczenia się zawarte w kwestionariuszu wywiadu wywołały emocje i obrazy, będące wskazówkami do wyszukiwania informacji i wspomnień zarówno z pamięci epizodycznej, jak i semantycznej. Oznacza to, że ich ogólne brzmienie nie tylko skłoniło do poszukiwania konkretnych przykładów edukacyjnych i towarzyszących im motywacji do podjęcia działania, ale także przywoływało zdarzenia, które nie miały miejsca w określonej czasoprzestrzeni. Co więcej, w momencie konfrontacji z ogólnymi stwierdzeniami badani chętniej odwoływali się właśnie do pamięci semantycznej, służącej przechowywaniu reguł, idei, ogólnych pojęć dotyczących świata - często uogólnień lub wyobrażeń dotyczących zdarzeń, doświadczeń 
i nabytej wiedzy (Matsumoto, Juang 2007). To dlatego obok wymienionych $\mathrm{w}$ poprzednim akapicie kontekstów funkcjonowania uczenia się pojawiły się nowe, związane z potocznym rozumieniem określenia oderwane od edukacji i procesów z nią związanych, zatem stojące $\mathrm{w}$ sprzeczności $\mathrm{z}$ ramami definicyjnymi przyjętymi przez badaczy. Podobnie jak w przypadku pomiaru poziomu uczestnictwa $\mathrm{w}$ nieformalnych działaniach edukacyjnych, tak w zakresie badania postaw względem uczenia się szczególnie problematyczne okazało się rozszerzanie przez część badanych znaczenia uczenia się na działania niemające charakteru intencjonalnego. Respondenci przywoływali szereg sytuacji, w których tak rozumiane uczenie się można sprowadzić do pewnej predyspozycji, właściwości percepcji każdego człowieka, niewymagającej od niego podejmowania innych czynności poza tymi należącymi do rutyny dnia codziennego. Czytając, korzystając z Internetu, oglądając telewizję czy prowadząc rozmowę - w każdej z tych sytuacji mamy szansę dowiedzieć się, nauczyć się czegoś nowego - w szerokim, potocznym tego słowa znaczeniu. Tak rozumiane uczenie się to także immanentna właściwość życia. Badani zwracali uwagę, że wraz z biegiem lat człowiek nabywa doświadczenia i mądrości: starzejąc się lub przystosowując do zmieniającej się rzeczywistości.

B: „W każdym wieku uczenie się ma sens”.

R: To znaczy zdecydowanie się zgadzam z tym. Ten piąty punkt. Ze względu na to, że, no, to jest, uczenie, to jest już podstawa naszego życia jako takiego. Bo cofamy się z... jeżeli czegoś tam nie zobaczymy, co nawet przez... uczenie, przez tą teraz obecnie telewizję, przez Internet to samoistnie następuje jako takie, uczenie. Coś nam... jeżeli kogoś coś zainteresuje, to sobie sprawdzi. Jak nie, to nie, to... Ale to potrzeba chwili jest. [...]
B: „Ważne jest dla mnie, aby wzbogacać swoją wiedzę lub... i/lub umiejętności".

R: To tak, jak powiedziałem, że nawet samoistnie, przez przymus. Zdecydowanie. No życie zmusza jako takie do tego tu. [W. 2]

Na poziomie semantycznym $\mathrm{w}$ wypowiedziach badanych pojawiały się także związki frazeologiczne odwołujące się w sposób pośredni lub bezpośredni do uczenia się, potwierdzające jego, powtarzając za respondentem, "samoistność", na przykład: podróże kształca, uczyć się na błędach lub wartość: uczysz się dla siebie, nauka nie idzie w las. Postrzeganie uczenia się w kategoriach zdroworozsądkowych utrudniało przekierowanie perspektywy badanych na konkretne działania edukacyjne. Skonfrontowani z szeregiem ogólnych stwierdzeń dotyczących uczenia się okazywali poirytowanie, postrzegając to zjawisko jako niewarte głębszego namysłu, oczywistą prawdę, nad którą nie trzeba się pochylać, lub doszukiwali się ukrytych znaczeń. Dążąc do zachowania równowagi między korzystaniem przez respondentów z łatwo dostępnych poznawczo informacji, przechowywanych w pamięci semantycznej, a próbami ich zobiektywizowania poprzez przywoływanie wspomnień zdarzeń przechowywanych w pamięci epizodycznej, zdecydowano się w kwestionariuszu przeznaczonym do badania właściwego przeformułować część stwierdzeń. Ogólne we wcześniejszym brzmieniu zdania odniesiono bezpośrednio do badanego poprzez zastosowanie formy pierwszoosobowej. Podjęto również decyzję o usunięciu części, zwłaszcza tych, które były odbierane jako oczywiste, niewarte podjęcia polemiki. Zdecydowano się także ograniczyć liczbę stwierdzeń, szczególnie jeśli podczas wywiadu były oceniane przez badanych jako dublujące się, między innymi, na przykład: $W$ każdym wieku uczenie się ma sens utożsamiano z Uczenie się jest dla dzieci i młodzieży, a nie dla dorostych. 


\section{Pomiar na skalach}

W pierwotnej wersji kwestionariusza w pytaniach, w których zastosowano pięciostopniową skalę Likerta lub skalę typu Likert', wykorzystano cztery typy etykiet, zależnie od tego, czy respondent proszony był o: wyrażenie stopnia zgadzania się z danym stwierdzeniem (odpowiedzi od zdecydowanie sie nie zgadzam do zdecydowanie się zgadzam), wskazanie, na ile dane stwierdzenie jest prawdziwe $\mathrm{w}$ odniesieniu do jego sytuacji (od zdecydowanie nie do zdecydowanie tak), określenie znaczenia, jakie ma dla niego przedstawiona kwestia (od w ogóle nieistotny do bardzo istotny), ocenę stopnia podobieństwa przedstawionych opisów do własnych doświadczeń (od to zupetnie nie przypomina moich wspomnień do to bardzo przypomina moje wspomnienia). Ostatnie $\mathrm{z}$ wymienionych podejść zastosowane było w bloku pytań dotyczących wspomnień $\mathrm{z}$ wczesnych lat szkolnych ${ }^{7}$. Pomimo posługiwania się kartami odpowiedzi, badanym zdarzało się spontanicznie wykorzystywać skalę zawierająca prostsze zwroty: od zdecydowanie nie do zdecydowanie tak. Zaobserwowana $\mathrm{w}$ wywiadzie nieintuicyjność posługiwania się zaproponowanym formatem odpowiedzi sprawiła, że ponownie przeanalizowano wybór skali w omawianym bloku pytań. Pomimo że pierwotna postać odpowiedzi, pod względem językowym, nieco lepiej odpowiadała zadanemu pytaniu, ostatecznie podjęto decyzję o zastosowaniu stwierdzeń mniej skomplikowanych i łatwiejszych do wykorzystania przez respondenta $\mathrm{w}$ wywiadzie CAPI - od zdecydowanie nie do zdecydowanie tak.

\footnotetext{
${ }^{6}$ Omówione tu skale w większości nie służą badaniu zgadzania się ze stwierdzeniami, a zatem, jak piszą Likert i Hayes (1961 za: Nadler, Weston, Voyles 2015), powinny być raczej określane mianem skal typu Likert, a nie skalami Likerta.

${ }^{7}$ Przedstawione były one w postaci zdań sformułowanych w pierwszej osobie, przykładowa pozycja z tego bloku to Dobrze czułem(am) się wśród osób ze swojej klasy.
}

Kolejnym problemem związanym z pięciostopniową skalą było brzmienie etykiety opcji środkowej. Pierwotnie, zarówno w przypadku odpowiedzi od zdecydowanie nie do zdecydowanie tak, jak i dla kategorii od zdecydowanie się nie zgadzam do zdecydowanie się zgadzam, środek skali opisany był zwrotem zawierającym przeczenia, odpowiednio: ani tak, ani nie i ani się zgadzam, ani się nie zgadzam. To popularne rozwiązanie stosowane było między innymi w badaniu European Social Survey, a także na przykład w polskiej Diagnozie społecznej czy w Bilansie kapitału ludzkiego. W toku wywiadów kognitywnych okazywało się jednak, że formuła zawierająca przeczenia bywała dla respondentów nieintuicyjna, co ilustrować może następujący fragment: „B: Czyli raczej się pani zgadza czy raczej się nie zgadza? Może przeczytam całą skalę. (...) R: I tak, i nie. B: Aha, czyli ta trzecią, ani się zgadzam, ani się nie zgadzam. R: No, tak by było" [W. 5].

Podjęta została więc decyzja o zmianie etykiet opcji środkowych na nieco bardziej potoczne: trochę sie zgadzam, troche nie zgadzam i troche tak, troche nie. Taki sposób sformułowania odpowiedzi zastosowany był w przywołanym wyżej bloku dotyczącym wspomnień z wczesnych lat szkolnych i nie sprawiał problemów respondentom. Wydaje się też być bardziej odpowiedni niż ani tak, ani nie, gdy pytania dotyczą faktów. Przykładem może być tu odpowiedź rozmówczyni na pytanie o uczestniczenie jej znajomych w działaniach typu kursy, szkolenia: „R: A jak uczestniczy z nich połowa, to które zaznaczymy [uśmiech]? B: No właśnie, które by pani wybrała? Bo myślę, że... R: Ja to chyba tą, w połowie takie. B: Ani się zgadzam, ani się nie zgadzam, tak? R: No właśnie" [W. 7]. Co więcej, można przypuszczać, że wykorzystanie sformułowań wyrażających wprost częściowe poparcie dla stwierdzeń pozwala zmniejszyć niejasność w zakresie interpretacji 
udzielonej odpowiedzi. Wybieranie opcji ani... ani... przez respondenta często bywa interpretowane jako brak zdania czy utożsamiane $\mathrm{z}$ odpowiedzią nie wiem (Baka, Figgou, Triga 2012; Nadler Weston, Voyles 2015), mimo że umiejscowienie kategorii pośrodku skali wyrażać powinno raczej posiadanie opinii, ale do pewnego stopnia zgodnej, a do pewnego niezgodnej z przedstawionym stwierdzeniem (Lam, Allen, Green 2010 za: Baka, Figgou, Triga 2012).

\section{Drażliwość pytań}

Jak wcześniej wspomniano, kluczowe dla realizacji celów projektu badawczego jest zidentyfikowanie poziomu uczestnictwa osób dorosłych $\mathrm{w}$ różnych formach działań edukacyjnych w ramach trzech typów uczenia. Omówione powyżej problemy związane z rozumieniem terminów współwystępują z problemami wywołanymi przez drażliwość poruszanych zagadnień. Samo przejście przez kolejne aktywności $\mathrm{w}$ ramach uczenia formalnego i pozaformalnego rodziło negatywne odczucia i wywoływało dyskomfort badanych. Należy oddzielić jednakże sygnały świadczące o irytacji spowodowanej samą uciążliwością długiego, złożonego pytania od tych, które świadczą o wpływie na emocje ze względu na poruszanie wątku wywołującego wstyd czy frustrację.

Znaczy, powiedzmy, śledziłem pewne rzeczy, ale nie brałem bezpośredniego udziału. [W.2]

Nie. Ale słyszałem o tych kursach. (...) Jakoś tak nie mam przekonania do nich. [W. 3]

R: [zastanawianie się] No, no byłam tam na jakimś wykładzie.

B: Jaki to był wykład?

R: Nie pamiętam. Wie pani co, za dużo się powtarza tych samych rzeczy tutaj.
B: Yhm.

R: Takie, to się takie robi, takie uciążliwe aż. [W. 7]

Rozmówcy podawali te same aktywności przy pytaniach dotyczących różnych rodzajów działań edukacyjnych, co z jednej strony może być efektem trudności w definiowaniu i rozróżnianiu użytych terminów, z drugiej sposobem na unikanie odpowiedzi negatywnej - redukowaniem dyskomfortu, chęcią ochrony własnej samooceny i realizacji antycypowanych oczekiwań osoby prowadzącej wywiad.

Przystępując do odpowiedzi na pytania z bloku dotyczącego uczenia się nieformalnego, badani mogli już czuć się zmęczeni i poirytowani po pytaniach dotyczących uczenia się w zorganizowanych formach. Zaobserwowano, że rozmówcy przytakuja w większości wymienianych form uczenia się, czasami z nutą niepewności: „no, w sumie tak; coś takiego było, zdarzało się". Z rozwinięcia wypowiedzi rozmówców wynika, że uwzględniali również uczenie się nieintencjonalne - „człowiekowi coś tam wpada do głowy; cały czas się człowiek uczy”. Co również można interpretować jako sposób na zmniejszenie poczucia dyskomfortu, próbę obrony przed uczuciem wstydu, niedopasowania do obowiązujących wzorców kulturowych. Obserwacje przeprowadzone $\mathrm{w}$ trakcie pierwszych wywiadów skłoniły do uproszczenia poruszanych wątków, a jednocześnie pogłębienia zagadnienia. Zmiana w scenariuszu wywiadu kognitywnego obejmowała dodanie pytań dotyczących charakterystyki i zakresu uczenia się przez rozmówców odpowiadających twierdząco na pytania o uczestnictwo, na przykład, jeśli badany odpowiedział twierdząco na pytanie o samodzielne uczenie się z książek, to proszony było o rozwinięcie, czego się uczył, w jakich okolicznościach. Starano się w ten sposób zweryfikować, na ile uczenie się nieformalne, które wskazują respondenci, wpisuje 
się w przyjętą definicję uczenia się. Zmiany dokonane w kwestionariuszu wywiadu, opisane powyżej, w ramach problematyki zrozumiałości, odpowiadają również na problemy związane z drażliwością.

Przystępując do badań społecznych, zawsze narusza się sferę prywatności badanych, jednak prośba dotycząca wyrażenia opinii czy opowiedzenia o swoich doświadczeniach jest uznawana za uprawnioną ze względu na cel przyświecający badaniom społecznym. Badacze dają przestrzeń respondentom do omijania zagadnień zbyt problematycznych, podkreślając w aranżacji, że zawsze mogą odmówić udzielenia odpowiedzi na pytanie, z drugiej jednak strony dąży się do uzyskania jak największej liczby odpowiedzi znaczących. Wykorzystanie wywiadów kognitywnych $\mathrm{w}$ ramach pilotażu narzędzia głównego miało służyć również do ustalenia granicy pomiędzy wejściem za daleko $\mathrm{w}$ intymną sferę rozmówcy a chęcią pozyskania danych, które uznane zostały za istotne z punktu widzenia realizacji celów badawczych.

Prowadzona na bieżąco analiza w trakcie wywiadów w pracowni focusowej oraz późniejsza analiza transkrypcji pozwalają wskazać dwa obszary, w których w największym stopniu zauważyć można dyskomfort rozmówców wywołany naruszeniem sfery prywatności. Są to: satysfakcja z osiągniętego poziomu wykształcenia oraz odniesienia do osób bliskich.

W przypadku rozmówców, którzy przyznali, że nie doszli do satysfakcjonującego poziomu, pytanie o zadowolenie $\mathrm{z}$ osiągniętego wykształcenia połączone było z pytaniem o przyczynę tego stanu rzeczy. Następowała więc obciążająca emocjonalnie sekwencja - uświadomienie sobie braku osiągnięcia, ujawnienie tego innej osobie (prowadzącej wywiad) i następnie konieczność sformułowania wyjaśnienia. W tym celu konieczny był powrót pa- mięcią do przyczyn sytuacji, która do tego doprowadziła. W trakcie prowadzonej obserwacji można było zauważyć wzrastający dosyć gwałtownie poziom irytacji u niektórych rozmówców, okazywany w sposób werbalny czy niewerbalny: zmieniony podniesiony głos czy jego zmieniony tembr. „Czemu nie ukończyłam? No mówię, no z lenistwa, no tak rozumiem. No czemu pani tego nie ukończyła, czemu pani tego nie robiła - no nie chciało mi się, no, iść wyżej czy coś tam. Później jedno dziecko. I to już tak się zaczęło" [W. 11]. Badani formułowali wypowiedzi będące racjonalizacją czy też chęcią wytłumaczenia się przed osobą realizującą wywiad, w niektórych wypadkach również dające wyraz niezadowoleniu z omawianej sytuacji:

Wyszłam za mąż i w niecały rok urodziłam dziecko i po prostu inne powody, poświęcenie się, że tak powiem. Potem szybko wróciłam do pracy i to $\mathrm{mi}$ umknęło. A potem cały czas sobie obiecywałam, doszły inne, że tak powiem problemy. [W. 1]

Chciałem, tak prawdę mówiąc, co ja chciałem, nie, no, to dzisiaj pani mnie pyta takie osobiste rzeczy. Wtedy była ważna rodzina, dzieci, jakiś taki socjal, zabezpieczenie. Dobrze, zrobiłem dobrze. Skończyłem to, co chciałem i jest dobrze. [W. 12]

Reakcje rozmówców wyraźnie wskazywały, że jest to problematyczny obszar, zarówno z perspektywy naruszenia prywatności, jak i oddziaływania na poczucie własnej wartości. Jednakże z perspektywy celów badawczych trudno pominać kwestię osiągniętego poziomu wykształcenia i ewentualnych prób jego uzupełniania. Przystępując do pilotażu, zakładano, że na podstawie analizy odpowiedzi przygotowana zostanie kafeteria, jednakże ze względu na zauważalny dyskomfort i negatywne reakcje emocjonalne respondentów zrezygnowano 
z pogłębienia tego wątku w badaniu Uczenie się dorostych Polaków. Pozostawiono jedynie pytanie zamknięte: Prosze powiedzieć, czy, ogólnie rzecz biorac, osiagnałtęta) Pan(i) taki poziom wykształcenia, jaki chciat(a) Pan(i) osiagnaćc Zaprojektowano jednocześnie inne rozwiązania w kwestionariuszu wywiadu, pozwalające powiązać osiągnięty poziom wykształcenia i dokształcanie po zakończeniu typowej ścieżki edukacyjnej ze zmiennymi z innych obszarów.

Jednym $\mathrm{z}$ analizowanych zagadnień $\mathrm{w}$ badaniu Uczenie się dorostych Polaków jest wpływ rodziny, otoczenia społecznego na postawę wobec uczenia się, w tym uczestnictwo w różnych aktywnościach edukacyjnych. $\mathrm{W}$ badaniu pilotażowym $\mathrm{w}$ niewielkim stopniu testowano pytania zawierające odniesienie do rodziny pochodzenia, szerzej reprezentowane były zagadnienia dotyczące osób, z którymi respondent pozostawał w bliskich relacjach w ostatnim czasie. W trakcie wywiadów zaobserwowano, że użyte określenia bliskie osoby czy bliscy są obciążone ryzykiem wywołania znacznego dyskomfortu rzutującego na dalszą część wywiadu. Niektórzy rozmówcy reagowali nerwowością, niechęcią do kolejnego bloku pytań, można było wyczuć zmianę atmosfery wywiadu.

R: To znaczy nic już teraz. Rodzina już dalej jest. Córka żonata i tak dalej. To już odpada. Żony nie ma. To nie ma. Psa nie ma. To też pies nie nauczy. (...) Znaczy, może tego punktu może w ogóle nie, bo, bo, bo nie mam możliwości. Teraz nie mam rodziny. Córka gdzie indziej mieszka. [W. 6]

Wyraźniej dostrzegano problematyczność tego sformułowania dla starszych respondentów, co zapewne wiąże się z większą różnorodnością doświadczeń życiowych. W ramach modyfikacji kwestionariusza wywiadu zdecydowano o pozostawieniu słowa bli- scy jedynie w neutralnych kontekstach, na przykład definiowaniu sytuacji osób niepracujących zawodowo, zajmujących się domem. W pytaniach dotyczących uczenia się nieformalnego od/z innymi osobami zastosowano bardziej neutralne sformułowanie ludzie, w moim najbliższym otoczeniu oraz zestawienie rodzina i/lub znajomi, wychodząc z założenia, że pozwoli to zmniejszyć ryzyko wystąpienia sytuacji, w której respondenci konfrontowani są z koniecznością odniesienia się do trudnych relacji.

\section{Wnioski}

Wnioski sformułowane na podstawie analizy wywiadów kognitywnych możemy rozważać na różnych poziomach - odnieść je bezpośrednio do omawianego projektu, szerzej - do badania zjawiska uczenia się osób dorosłych czy w jeszcze bardziej ogólny sposób - do badań sondażowych. Ponadto można sformułować również konkluzje dotyczące realizacji badań z wykorzystaniem tej metody. Modyfikacje wprowadzone do kwestionariusza wywiadu dotyczące sposobu operacjonalizacji, konstrukcji pytań, zakresu kategorii czy ograniczenia objętości narzędzia zwiększają szansę na uzyskanie wiarygodnych, trafnych wyników, a tym samym na zmniejszenie błędu pomiaru. Ograniczają ryzyko związane $\mathrm{z}$ niezrozumieniem pytań zgodnie $\mathrm{z}$ intencją badacza, podwójnym klasyfikowaniem działań, znużeniem czy też dyskomfortem wynikającym z niepewności respondentów co do znaczenia pojęć.

Odtworzenie sposobu konceptualizacji oraz klasyfikowania pojęć przez badanych dostarczyło argumentów, aby w inny sposób niż dotychczas realizowany $\mathrm{w}$ badaniach uczenia się dorosłych formułować niektóre z kluczowych pytań dotyczących podejmowanych aktywności w ramach uczenia się pozaformalnego i nieformalnego oraz określać za- 
kres kategorii uczenia się. Za uzasadnione, a nawet konieczne uznano łączenie takich form, typów uczenia, między którymi różnice okazywały się być dla badanych nieostre czy wręcz pomijalne. Szczegółowe, rozbudowane pytania nie dość, że sprawiały problem badanym ze względu na trudności z odpowiednim zaklasyfikowaniem podejmowanych aktywności edukacyjnych, to również wywoływały negatywne reakcje emocjonalne rozmówców nieaktywnych w zakresie uczenia się w dorosłości. Dzięki analizie przeprowadzonych wywiadów zwrócono także uwagę na zagadnienia, które w praktyce przygotowania kwestionariusza zazwyczaj nie podlegają pogłębionej refleksji, wiążą się z wykorzystaniem rozwiązań standardowych dla badań sondażowych. Podążając za sposobem formułowania uzasadnień i ścieżką dokonywania wyboru odpowiedzi przez badanych, zmodyfikowano etykietę opcji środkowej na skali typu Likert. W tym przypadku reakcje rozmówców na pytania sprawiły, że podano w wątpliwość zasadność stosowania sformułowań znanych badaczom, ale niekoniecznie dostępnych poznawczo respondentom. Dostrzegając natomiast, że w niektórych przypadkach problemy ze zrozumiałością i drażliwością pytań nie tylko współwystępowały, ale także wzajemnie się wzmacniały, rezygnowano z używania zwrotów, a nawet całych pytań, które uznano za najbardziej obciążające.

Podsumowując przeprowadzone badanie, warto również zwrócić uwagę na pewne kwestie związane z samą techniką wywiadów kognitywnych. Dążąc do jak największej użyteczności pierwszego etapu pilotażu, zdecydowano o połączeniu techniki wywiadów kognitywnych z elementami wywiadu jakościowego. Pogłębienie interpretacji wykorzystywanych zwrotów czy stwierdzeń pozwoliło lepiej zrozumieć perspektywę respondenta. Należy również wspomnieć, że podejście thinking aloud okazało się trudne do realizacji dla badanych, w pewnym stopniu nienaturalne i powodujące swoisty dyskomfort. W konsekwencji pytania realizowane $\mathrm{z}$ zastosowaniem tej techniki dostarczały mniejszą ilość danych, niż spodziewano się uzyskać. Być może spowodowane to było ograniczonym treningiem dotyczącym refleksyjnego wypowiadania się, budowania argumentacji czy kompetencjami językowymi ograniczającymi możliwości realizacji zadania zgodnie z intencją badacza. Z drugiej zaś strony można było odnieść wrażenie, że niektóre z poruszanych zagadnień traktowane były przez badanych jako na tyle błahe i codzienne, że nie warte głębszej refleksji i dyskusji lub na tyle prywatne, że respondenci nie chcieli zagłębiać się w szczegóły. Zastosowanie modelu hybrydowego - połączenia technik thinking aloud oraz verbal probing w ramach jednego wywiadu wydaje się więc zasadne. Pytania kwestionariuszowe różnią się między sobą nie tylko sposobem sformułowania, lecz także i poziomem oczekiwanej od respondenta autorefleksji, zatem sprawdzanie ich zrozumiałości tą samą techniką wydaje się w tym kontekście nietrafne, a przynajmniej niedostarczające odpowiedniej wiedzy badaczowi.

Interesującą kwestią zaobserwowaną $\mathrm{w}$ przypadku pytań, które zadawano respondentom najpierw w otwartej, a później w zamkniętej formie, było modyfikowanie informacji uprzednio podanych spontanicznie, po zobaczeniu proponowanej kafeterii odpowiedzi. Badani decydowali się na przykład na rozszerzenie swojej wcześniejszej odpowiedzi i wskazanie większej liczby pasujących możliwości (co dotyczyło również sytuacji, gdy spontaniczna odpowiedź znajdowała swoje odzwierciedlenie w kafeterii) lub też wybierali odpowiedź, która nie do końca była zgodna z jej wcześniejsza, spontaniczną interpretacją. Działanie to mogło być konsekwencją zarówno odczuwanego przez respondenta dys- 
komfortu wynikającego z sytuacji badania i chęci udzielenia szybko odpowiedzi na pytanie otwarte, jak i posługiwania się przez niego innym zakresem znaczeniowym pojęć użytych w pytaniu czy też wynikać z trudności ze spontanicznym przywołaniem wszystkich pasujących odpowiedzi z pamięci.

Zastosowanie wywiadów kognitywnych było eksploracją procesów poznawczych respondentów, w tym „ścieżek dotarcia do odpowiedzi” i skojarzeń, które mogą być zupełnie odmienne od zamysłu badaczy projektujących narzędzie. Analiza wyników umożliwiła lepsze zrozumienie problemów, których wystąpienie przewidywano na podstawie przeglądu literatury. Uwydatniła także zagadnienia, które mogą być obciążające emocjonalnie dla badanych i wywoływać ich dyskomfort. Zachowanie „świeżego spojrzenia" i wrażliwości badawczej nawet w przypadku zjawisk, które nie wydają się drażliwe, jak aktywność w zakresie edukacji, okazało się jednym z kluczowych elementów projektowania kwestionariusza. Ważne jest utrzymanie równowagi pomiędzy dążeniem do uzyskania szczegółowych, istotnych i wiarygodnych wyników a zachowaniem zarówno standardów etycznych, jak i wrażliwości na respondenta i jego dobrostan. Warto pamiętać również, że badając takie zagadnienia jak edukacja, trzeba szczególnie refleksyjnie podchodzić do narzędzia, ze świadomością, że zjawisko uczenia jest również częścią doświadczeń badaczy, którzy mają specyficzną sytuację w tym zakresie: przeszli wydłużoną ścieżkę edukacji

\section{Bibliografia}

Baka Aphrodite, Figgou Lia, Triga Vasiliki (2012) Neither agree, nor disagree: a critical analysis of the middle answer category in Voting Advice Applications. „International Journal of Electronic Governance, vol. 5, no. 3-4, s. 244-261. formalnej i pracują w środowisku skłaniającym do podejmowania dalszych aktywności edukacyjnych.

Przedstawione w tym artykule badanie pilotażowe obrazuje, że analiza zagadnień, które wydają się proste i łatwo dostępne respondentom, właśnie ze względu na tę pozorną prostotę powinna być wyjątkowo uważnie przygotowywana. Na szczególną uwagę zasługują przy tym zjawiska, które, jak uczenie się dorosłych, dostępne są codziennym doświadczeniom, ich potoczne rozumienie odbiega od naukowych definicji, a sposób pomiaru nie doczekał się jednej, ogólnie akceptowanej metody. Ze względu na nieskomplikowaną na pozór tematykę oraz dostępność opracowań innych autorów łatwo w tego typu badaniach zdecydować się na już istniejące rozwiązania. Pomija się wówczas między innymi problemy, na których zidentyfikowanie pozwalają tylko metody jakościowe. Wspomaganie przygotowania badań ilościowych metodami jakościowymi poszerza perspektywę i pozwala wyjść poza własne ramy interpretacyjne, w których często, pomimo najlepszych chęci, zamknięty bywa sposób myślenia zespołów badawczych. Poprzez pogłębione testowanie narzędzi badawczych, konfrontację przyjmowanych rozwiązań z rozmówcami charakteryzującymi się różnymi doświadczeniami, kompetencjami, zasobami możemy dążyć do sformułowania pytań pozwalających na uzyskanie wyników bardziej trafnych i wiarygodnych, a jednocześnie mniej obciążających dla respondentów.
Ciccolo Gia i in. (2020) Improving Understanding of Screening Questions for Social Risk and Social Need Among Emergency Department Patients. „The western journal of emergency medicine”, vol. 21, no. 5, s. 1170-1174. 
Desjardins Richard (2014) Participation in Adult Education Opportunities: Evidence from PIAAC and Policy Trends in Selected Countries. Background Paper for the Education for All Global Monitoring Report 2015. UNESCO [dostęp 10 czerwca 2020 r.]. Dostępny w Internecie: https://unesdoc.unesco.org/ark:/48223/ pf0000232396.

Eurostat (2016) Classification of learning activities (CLA) manual 2016 Edition, European Union, Luxemburg [dostęp 12 maja 2020 r.]. Dostępny w Internecie: https://ec.europa.eu/eurostat/documents/3859598/7659750/KS-GQ-15-011-EN-N.pdf>.

Goglio Valentina, Elena Claudia Meroni (2014) Adult Participation in Lifelong Learning: Technical Briefing. European Commission, Joint Research Centre, Econometrics and Applied Statistics Deputy Director-General Office. Luxembourg: Publications Office.

Groves Robert M. i in. (2004) Survey Methodology. Hoboken, NJ: John Wiley and Sons.

Grzeszkiewicz-Radulska Katarzyna (2012) Metody badań pilotażowych. "Acta Universitatis Lodziensis. Folia Sociologica”, vol. 42, s. 113-141.

Jabkowski Piotr (2015) Reprezentatywność badań reprezentatywnych. Analiza wybranych problemów metodologicznych oraz praktycznych w paradygmacie całkowitego błędu pomiaru. Poznań: Wydawnictwo Naukowe Uniwersytetu im. Adama Mickiewicza, Seria Socjologia nr 77.

Kubiak Anna, Przybyłowska Ilona, Rostocki Włodzimierz Andrzej (1992) Społeczna przestrzeń wywiadu kwestionariuszowego [w:] Zygmunt Gostkowski, red., Analizy i próby technik badawczych w socjologii. Problemy humanizacji procesu badawczego, t. 9. Warszawa: Wydawnictwo IFiS PAN, s. 69-101.

Lavrakas Paul J. (ed.) (2008) Encyclopedia of survey research methods. Thousand Oaks, CA: SAGE Publications.

Liani Serena, Martire Fabrizio, Pitrone Maria C. (2015) Cognitive Interviewing to Pretest Attitude Questions. „Italian Sociological Review", vol. 5, no. 2, s. 237-250.

Lutyńska Krystyna (2000) Problemy drażliwe w badaniach socjologicznych w Polsce. "ASK. Społeczeństwo. Badania. Metody", nr 9, s. 51-63.

Matsumoto David Ricky, Juang Linda (2007) Psychologia międzykulturowa. Przełożyła Agnieszka Nowak. Gdańsk: Gdańskie Wydawnictwo Psychologiczne.
Nadler Joel, Weston Rebecca, Voyles Elora (2015) Stuck in the Middle: The Use and Interpretation of Mid-Points in Items on Questionnaires. „The Journal of General Psychology”, vol. 142, no. 2, s. 71-89.

Nowak Stefan (1973) Pojęcie postawy w teoriach $i$ stosowanych badaniach społecznych [w:] Stefan Nowak, red., Teorie postaw. Warszawa: Państwowe Wydawnictwo Naukowe, s. 17-88.

Priede Camilla, Farrall Stephen (2010) Comparing results from different styles of cognitive interviewing: 'verbal probing' vs. 'thinking aloud'. „International Journal of Social Research Methodology", vol. 14, no. 4, s. 271-287.

Rubenson Kjell (2019) Assessing the status of lifelong learning: Issues with composite indexes and surveys on participation. „International Review of Education / Internationale Zeitschrift für Erziehungswissenschaft", vol. 65, no. 1, s. 295-317.

Ryan Katherine, Gannon-Slater Nora, Culbertson Michael J. (2012) Improving Survey Methods With Cognitive Interviews in Small- and Medium-Scale Evaluations. "American Journal of Evaluation", vol. 33, no. 3, s. 414-430.

Sopromadze Natia, Moorosi Pontso (2016) Do we see through their eyes? Testing a bilingual questionnaire in education research using cognitive interviews. "Journal International Journal of Research \& Method in Education", no. 40, s. 524-540 [dostęp 15 czerwca 2020 r.]. Dostępny w Internecie: ‘http://dx.doi.org/10.1080/17437 27X.2016.1181163>.

Stec Katarzyna i in. (2018) Bilans Kapitału Ludzkiego 2017. Rozwój kompetencji - uczenie się osób dorostych i podmioty oferujace ustugi rozwojowe. Badanie przeprowadzone na zlecenie Polskiej Agencji Rozwoju Przedsiębiorczości [dostęp 20 czerwca 2020 r.]. Dostępny w Internecie: 〈https://www.parp.gov.pl/storage/ publications/pdf/Rozwoj-kompetencji----uczenie-sie-osob-doroslych_200129.pdf».

Sztabiński Franciszek (2011) Ocena jakości danych w badaniach surveyowych. Warszawa: Wydawnictwo IFiS PAN.

Tourangeau Roger (1984) Cognitive Sciences and Survey Methods [w:] Thomas. B. Jabine i in., eds., Building a Bridge Between Disciplines: Report of the Advanced Research Seminar on Cognitive Aspects of Survey Methodology. Washington, DC: National Academy Press, s. 73-100.

Tourangeau Roger, Bradburn Norman M. (2010) The psychology of survey response [w:] James D. Wright, Peter V. Marsden, eds., Handbook of survey research. West Yorkshire: Emerald Group, s. 315-346. 
Van Someren Maarten W., Bernard Yvonne. F., Sanberg Jacobijn A. C. (1994) The think aloud method. A practical guide to modeling cognitive processes. London: Academic Press.

Willis Gordon B. (2005) Cognitive Interviewing. A Tool for Improving Questionnaire Design. Thousand Oaks, CA: Sage Publications.

Willis Gordon B. (2015) Analysis of cognitive interview in questionnaire design. NY: Oxford University Press.
Willis Gordon B. (2018) Cognitive Interviewing in Survey Design: State of the Science and Future Directions [w:] David L. Vannette, Jon A. Krosnick, eds., The Palgrave Handbook of Survey Research. London: Palgrave Macmillan, s. $103-107$.

Worek Barbara (2019) Uczace się społeczeństwo. O aktywności edukacyjnej dorostych Polaków. Kraków: Wydawnictwo Uniwersytetu Jagiellońskiego.

\title{
Cytowanie
}

Adamczyk Paulina i in. (2021) Wykorzystanie wywiadów kognitywnych w projektowaniu kwestionariusza wywiadu na przykładzie badania uczenia się osób dorostych. „Przegląd Socjologii Jakościowej”, t. 17, nr 1, s. 136-158 [dostęp dzień, miesiąc, rok]. Dostępny w Internecie: 〈www.przegladsocjologiijakosciowej.org〉. DOI: http://dx.doi.org/10.18778/1733-8069.17.1.09

\section{Using Cognitive Interviews in Designing an Interview Questionnaire Based on the Example of a Study into Adult Learning}

\begin{abstract}
The article presents an analysis of the cognitive interviews that constituted the first stage of the pilot of the interview questionnaire as part of the "Adult Learning in Poland" study. The available results of international studies indicate a relatively low level of adult participation in education in Poland, whilst also pointing to differences in the values of indicators between the studies. From the literature review it can be concluded that these discrepancies result from differences in operationalization, ways of category aggregation, and other factors. It was assumed that the use of cognitive interviews, including the 'thinking aloud' and 'verbal probing' techniques, would make it possible for the respondents to find ways to interpret concepts and understand questions, as well as enabling the the researchers to identify issues with a high level of sensitivity. A discussion of the analysis of the collected empirical material; the methods of conceptualizing the terms used by the respondents; and the issues causing them discomfort - were all discussed based on the results of the observation conducted during the interviews. The proposed modifications of the interview questionnaire are presented. These changes were implemented in order to reduce the risk of obtaining incorrect results with a high risk of measurement error, and to ensure the well-being of the respondents during the interviews. The conclusions concerning the use of the cognitive interviewing technique as an element of the pilot survey - as well as the methodological conclusions regarding the cognitive interviewing technique - were also presented.
\end{abstract}

Keywords: cognitive interviews, adult education, pilot study 